\title{
Det endeløse essay
}

\author{
Carsten Jensen
}

En dag i efteråret 1990 - eller var det foråret? - jeg har glemt det - begyndte jeg at skrive på et endeløst essay. Jeg blev ikke færdig med det dengang. Jeg er stadig ikke færdig med det. Jeg bliver aldrig færdig med det. Det er et endeløst essay. Det handler om, hvad et essay er. Måske derfor.

Det hele begyndte, da jeg modtog en opfordring fra Forfatterforeningen - det var for splittelsen - til en aften i lokalerne i Strandgade at holde et foredrag om essayet. Jeg var uvant med at holde foredrag, altid nervøs, kun alt for bevidst om mit handicap, at min viden om de fleste emner er så mangelfuld, at den nok holder til en lille slagfærdig artikel $i$ en avis, men ikke til et længere ophold på et podium.

Jeg syntes dog, jeg havde et vist forhold til essaygenren, da jeg stort set lever af min associationsevne og takkede derfor ja, idet jeg samtidig besluttede, at jeg ville skrive hele foredraget ned ord for ord.

I løbet af et par dage havde jeg skrevet 35 tætskrevne sider, som jeg insisterede på at læse op fra ende til anden. Der var fem tilhørere, min daværende kone og en nær ven, som jeg havde fået lokket med, fordi jeg havde stillet ham en god middag i udsigt samt arrangøren selv og endelig to mig helt fremmede personer, som udgjorde det egentlige publikum.

Min forfængelighed befandt sig på det tidspunkt i et temmeligt sårbart stadie. Jeg havde forladt pressen samt en hel del virak og opmærksomhed og var gået ud $\mathrm{i}$ et tomrum med en tåget forestilling om at træde i karakter som forfatter. I den forbindelse havde jeg pålagt mig selv et forbud mod at optræde i nogen form for massemedier, et forbud, der skulle komme til at gælde $\mathrm{i}$ toethalvt år. Ret beset burde jeg altså have været glad for, at der kun kom to til- hørere til mit foredrag. Det var jeg ikke. Jeg var såret.

Men det var jo ikke nogens skyld. Jeg havde ingen andre at bebrejde end mig selv og mit allerede glemte navn, en temmelig nedslående tanke. Indtil jeg fik oplyst, hvordan mødet var blevet annonceret i Forfatterforeningens blad: Sådan skriver man et essay. Platheden bekræftede kun, hvad jeg i forvejen mente om Skriv-selv-foreningen med de I600 medlemmer og lettede et øjeblikket trykket på min sårede forfængelighed. Jeg havde heller ikke selv gidet møde op til et foredrag med den aftenskoleagtige titel.

Men min sårethed var ikke bare inkonsekvent. Den vidnede også om, at jeg ikke selv havde taget pointen i mit eget foredrag alvorligt. Jeg argumenterede for, at essaytraditionen i dansk litteratur efter en lovende begyndelse $i$ forrige århundrede efterhånden var gået død og kun havde overlevet $\mathrm{i}$ det uforpligtende causeris udvandede form som en bekræftelse på Jacob Paludans ord om danskerne, at vi ,utvivlsomt står svagest når det gælder den analytiske energi. Vi er magelige og lyriske." De kun to tilhørere var den mest overbevisende bekræftelse på rigtigheden af min tese, og jeg burde være gået tilfreds hjem ad Strandgade.

Jeg kom til at holde foredraget et par gange mere, bl.a. i Dansklærerforeningen, hvis medlemmer klagede over dets længde. Jeg blev også ved med hele tiden at skrive nyt til. En opfordring fra en højskole om at holde et foredrag om Poul Henningsen i anledning af ıoo-året for hans fødsel blev årsag til, at jeg tilbragte en sommer med at læse de fire bind udvalgte værker, som $R$ hodos havde udgivet $i$ halvfjerdserne, og som jeg havde haft stående på reolen i tyve år uden nogen sinde at åbne dem. Et nyt af- 
snit blev føjet til foredraget. Jeg læste Elsa Gress i mine forældres have i Aalborg, Montaigne i Venedig, Jean Starobinskis bog om Montaigne i Intercitytoget på vej til Skanderborg. Jeg indså, hvor mangelfulde afsnittene om Georg Brandes og Villy Sørensen var, og at læsepensumet her langt overgik de fire bind med udvalgte Henningsen-tekster. Jeg kikkede indenfor hos Knud Sønderby, Otto Gelsted, Per Lange, Frank Jæger, Thorkild Bjørnvig, Henrik Stangerup, Suzanne Brøgger, Hans-Jørgen Nielsen, Jørgen Bonde Jensen og mange andre. Søren Kierkegaard plagede mig. Med et højst nødtørftigt udgangspunkt i Frygt og Baven og Gjentagelsen havde jeg prøvet at læse ham som essayist og fokusere på hans stil fremfor hans livtag med teologien. Nu satte jeg mig for at komme igennem resten af hans produktion, og essayet forekom mere og mere endeløst, især da jeg også mente at måtte vejen om ad mine egne personlige læremestre, udanske personligheder som Hans Magnus Enzensberger og Umberto Eco, og desuden viklede mig ind $i$ en række tvivlsomme overvejelser over en ny romanhybrid, jeg bildte mig ind var på vej i reaktion på romantraditionens forarmelse. Den italienske forfatter Claudio Magris har med udgangspunkt i vor egen J. P. Jacobsen skrevet om en romantype med stærke, essayistiske træk, og det var denne tradition, jeg forsøgte at følge op gennem århundredet. Navne som Marcel Proust, Thomas Mann, Herman Broch og Robert Musil mindede på ingen måde om J. P. Jacobsen, men gik dog som han ugenert rundt indenfor en opfattelse af romanen, der var anderledes høj og vid end den nu herskende. Jeg mente at finde en ny blomstring hos så forskellige forfattere som Milan Kundera, Bruce Chatwin, Julian Barnes, Peter Schneider, Botho Strauss og Feliz de Azúa og stillede spørgsmålet, om det var essayisterne, der ,forlod den udtørrede tankes sprukne landmasser og søgte tilbage til vandet for at bade sig i romanens og sansningens anderledes foruroligende dybder," eller om det omvendt var „romanforfatterne, der trætte af sansningens våde element gik $i$ land for at mærke solen og tørre sig i tankens klarhed.“

I mellemtiden blev der krig i Golfen, så i Jugoslavien. Jeg tilføjede et afsnit om de intellektuelles rolle og sammenlignede deres reaktioner på de to krige, mens jeg gjorde mig forestillinger om demokrati, nation og behovet for intellektuel uafhængighed. Jeg diskuterede Golfkrig med Lars Gustafsson, Jean Beaudrillard, Paul Virilio og Tom Engelhardt, Bosnien med Hans Magnus Enzensberger og verdenssituation med Peter Schneider. Imens strøede jeg om mig med citater fra det mærkelige fransk-rumænske essay-geni E. M. Cioran, hvis navn jeg omsider lærte at udtale korrekt på en reportagetur til Bukarest for Ekstra Bladet. På dette tidspunkt indså jeg, at mit essay om essayet selvfølgelig ikke ville være komplet, hvis jeg blot nøjedes med at citere Cioran. Jeg måtte også tegne et portræt af ham og karakterisere det unikke ved hans essayistik. Jeg begyndte at indse det: Det var en endeløs opgave, jeg havde påtaget mig.

I efteråret 1992 forsøgte jeg at afslutte den ved simpelthen at offentliggøre det, jeg indtil nu havde nedskrevet. Essayet om essayet skulle stå i „Forsømmelsernes bog“, som udkom året efter. Men under indtryk af korrekturlæseren, som sagde, hun kedede sig, og den ene af mine to betroede førstegangslæsere, som hævdede, det var et stilbrud, tog jeg i sidste øjeblik teksten ud. Jeg var tilbage, hvor jeg startede: Med dette uformeligt voksende essay.

Jeg har haft to alvorlige kriser med det. (At jeg ikke arbejder på det og ikke har gjort det i de sidste par år, betragter jeg ikke som en krise, skønt dele af det forældes i samme takt, som nyt kommer til). Den første krise indtraf på en café i Venedig, den anden i Melbourne, hvor det var synet af Germaine Greer, der var årsagen.

Jeg ankom regelmæssigt hver dag til caféen, hvorfra der var udsigt over vandet til Guidecca og satte mig med en cappucino, mens jeg læste mig gennem de tre nyoversatte bind af Montaignes essays, som netop var udkommet. Krisen indtraf, da Montaigne begyndte at berette om sine nyresten. Han gør det ikke en gang. Han gør det flere. Jo ældre han bliver - hans essays er skrevet over en periode på næsten tyve år - desto kærere er emnet ham faktisk. Hvad, der var galt, var, at min definition på essayet ikke gav plads til nyresten. 
I mine studieår havde jeg læst Th. W. Adornos lille essay om essayet. „Essayet som form“, hed det, hvis min hukommelse ikke bedrager mig, hvad den somme tider gør. (Jeg havde essayet i fotokopi, ovenikøbet i norsk oversættelse og kan i dag ikke længere finde det $\mathrm{i}$ mit rodede bohave). Det hørte dengang til min yndlingslæsning af tre grunde: det var kort, det var en af min studietids få tekster, jeg var sikker på, jeg forstod, og det var fuld af smukke formuleringer - selv på norsk. Et eller andet ubevidst sted kom det at ligge til grund for mit endeløse essay om essayet, og jeg mener, at det er Th. W. Adorno, der må bære ansvaret - ihvertfald som inspirationskilde - for visse af mine formuleringer som f.eks. denne: „... i essayet konfronterer jeg' et sig med tanken selv, der hvor den er blevet hærdet i begrebernes, ismernes og filosofiernes støbeforme. Mens romanen er forpligtet på det usagte, er essayet forpligtet på det allerede sagte.“ Og et andet sted: „Essayet genstand er det allerede frembragte. Som kritik er det netop altid kulturkritik, dvs. det forholder sig til det allerede tænkte, skrevne og sagte. Det er ikke primært båret af føllelse, men af tanke.“

$\mathrm{Nu}$ er der jo ikke ret meget hverken isme, begreb eller filosofi over nyresten, ligesom det er vanskeligt at henregne dem under det allerede sagte, tænkte eller skrevne. Men her var nyrestenene altså, et centralt tema $i$ et essay skrevet af genrens ophavsmand og navngiver. Jeg havde kun et valg. Enten at revidere min definition eller også at ekskludere Montaigne fra essayisternes snævre kreds.

Som sagt: et endeløst essay.

Min næste krise indtraf, da jeg deltog i Melbournes Writers Festival og en eftermiddag overværede en paneldebat om essayet. Forskellige forfattere og akademikere gav indbyrdes modstridende, men altid meget præcise definitioner på essayet. Deres definitioner var så knivskarpe, at de alle sammen var nødt til at læse op fra deres manuskripter, da livsvigtige detaljer, som skulle profilere dem overfor eventuelle modstandere ellers risikerede at gå tabt. (Jeg genkendte det fra mig selv). Nogle mente, at essayet absolut skulle være humoristisk, andre, at det netop ikke skulle, nogle, at det nødvendigvis måtte være kort, andre at det helst skulle være langt, nogle, at det tog stilling, andre at det var en upartisk genre.

Så trådte Germaine Greer op på scenen. Jeg har aldrig set hende forr, og hun er et temmelig imponerende syn. Høj, store knogler, store træk, et kraftigt, uordentligt hår, og vel nok den grimmest klædte kvinde, jeg har set, hvad der dog ikke skjuler, at hun faktisk er ret tiltrækkende, selv nu hvor hun har nået en alder, hvor hun ikke ønsker at blive bedømt på sin udstråling. (Det er alt sammen sagen uvedkommende. Jeg nævner det alligevel). Hun talte uden manuskript, og hendes indlæg var tydeligvis improviseret på stedet, da hun det meste af tiden gjorde grin med de forudgående indlæg, som hun netop havde hørt for første gang. Hun gjorde opmærksom på alle de berømte essays, der ville falde udenfor definitionen, hvis et essay ikke måtte være humoristisk, og alle dem, der ville falde udenfor, hvis det absolut skulle, alle dem, der ikke ville passe til definitionen, hvis korthed var et kriterium, og alle dem, der måtte sendes uden for døren, hvis det kun måtte være langt, og endelig alle dem, der måtte ignoreres, hvis essayet enten ikke måttc være partisk eller netop skulle være det.

Til sidst sagde hun, at hun, hvis hun skulle give en definition på et godt essay ville henvise til de reportager, Radio BBC's udenrigskorrespondenter sendte hjem fra forskellige brændpunkter i verden, eftersom de havde en begyndelse og en slutning, man fik noget at vide indimellem, og desuden var der en tolkning af begivenhederne.

Jeg arbejder stadig på mit endeløse essay... 